\title{
Mapping of the transcription start site (TSS) and identification of SNPs in the bovine neuropeptide Y (NPY) gene Bojlul Bahar and Torres Sweeney*
}

Address: Cell and Molecular Biology Lab, School of Agriculture, Food Science \& Veterinary Medicine, Veterinary Science Centre, University College Dublin, Belfield, Dublin 4, Ireland

Email: Bojlul Bahar - bojlul.bahar@ucd.ie; Torres Sweeney* - torres.sweeney@ucd.ie

* Corresponding author

Published: 23 December 2008

BMC Genetics 2008, 9:91 doi:10.1/86/147|-2156-9-9|
Received: I August 2008

Accepted: 23 December 2008

This article is available from: http://www.biomedcentral.com/I47I-2I56/9/9I

(c) 2008 Bahar and Sweeney; licensee BioMed Central Ltd.

This is an Open Access article distributed under the terms of the Creative Commons Attribution License (http://creativecommons.org/licenses/by/2.0), which permits unrestricted use, distribution, and reproduction in any medium, provided the original work is properly cited.

\begin{abstract}
Background: Neuropeptide $Y$ is a key neurotransmitter of the central nervous system which plays a vital role in the feed energy homeostasis in mammals. Mutations in the regulatory and coding regions of the bovine NPY gene can potentially affect the neuronal regulation of appetite and feeding behaviour in cattle. The objectives of this experiment were to: a) fully characterize the bovine NPY gene transcript and $b$ ) identify the SNP diversity in both coding and non-coding regions of the NPY gene in a panel of Bos taurus and B. indicus cattle.
\end{abstract}

Results: Bovine NPY gene consists of four exons $(99,188,81$ and 195 nucleotides) and three introns. The promoter region of the NPY gene consists of TATA and GC boxes which are separated from the transcription start site (TSS) by 29 and $~ 100 \mathrm{nt}$, respectively. Analyses of the tissue specific expression of the bovine NPY gene revealed the presence of highly abundant NPY gene transcripts in the arcuate nucleus, cerebral and cerebellar regions of the bovine brain. We identified a total of 59 SNPs in the $8.4 \mathrm{~kb}$ region of the bovine NPY gene. Seven out of nine total SNPs in the promoter region affect binding of putative transcription factors. A high level of nucleotide diversity was evident in the promoter regions $\left(2.84 \times 10^{-3}\right)$ compared to the exonic $\left(1.44 \times 10^{-3}\right)$, intronic $\left(1.30 \times 10^{-3}\right)$ and $3^{\prime}$ untranslated $\left(1.26 \times 10^{-3}\right)$ regions.

Conclusion: The SNPs identified in different regions of bovine NPY gene may serve as a basis for understanding the regulation of the expression of the bovine NPY gene under a variety of physiological conditions and identification of genotypes with high feed energy conversion efficiency.

\section{Background}

Following concerns that methane emissions from ruminants are contributing to global warming, there is an increased demand for the development of sustainable agricultural production systems $[1,2]$. One component of such systems is the ability to be able to genetically select animals that can efficiently utilize feed energy $[3,4]$. This requires an understanding of the underlying genomic factors influencing energy conversion efficiency in rumi- nants. Neuropeptide $\mathrm{Y}$, a key neurotransmitter of the central nervous system which plays a vital role in the feed energy homeostasis in mammals, has the potential to serve as a candidate for the energy conversion in ruminants. Expression of the neuropeptide $\mathrm{Y}(N P Y)$ gene is considered to be a regulator of feed intake in cattle [5]. Neuropeptide Y influences a number of biological pathways regulating appetite, feeding behavior and energy homoeostasis in humans and animals [6-9]. Neuropep- 
tide $\mathrm{Y}$ was found to stimulate growth hormone secretion in cattle [10], to increase the expression of the leptin gene [11] in sheep, and to decrease free fatty acid secretion in adipocyte cell lines [12].

In cattle, the NPY gene is mapped to chromosome 4 [13]. The NPY gene codes for a functional peptide of 36 amino acid residues. This peptide is highly conserved across the mammalian species further indicating the physiological importance of the neuropeptide Y molecule [14]. It is likely that because of evolutionary conservation, the NPY gene harbors useful genetic variation in the regulatory regions [15]. To identify the promoter region and to distinguish between the coding and non-coding regions of the gene, it is important that the transcription start site (TSS) be accurately identified [16]. In silico identification of the TSS through computational methods is feasible, but such methods need further experimental verification [17]. A comparative genomic analysis, combined with the sequence information derived from the full length cDNA is identified as a technique of identification of the TSS [18-20].

Three SNPs were previously identified in the intronic regions of the bovine NPY gene [13]. However, currently no information is available on the extent of genetic diversity present in the promoter and exonic regions of the bovine NPY gene. SNPs in the promoter region may affect binding of transcription factors and thus influence the expression of the NPY gene. Hence, the objectives of this experiment were to: a) fully characterize the bovine NPY gene transcript and $b$ ) identify the SNP diversity in both coding and non-coding regions of the NPY gene in a panel of Bos taurus and B. indicus cattle.

\section{Results}

\section{In silico comparative sequence analysis of NPY gene}

The NCBI/Ensemble available 5' untranslated region and the first available exon of the bovine NPY gene [GeneBank: AY491054] were compared to the orthologous sequences from the horse [Ensembl: ENSECAG0000 0008726], mouse [Ensembl: ENSMUSG00000029819], rat [Ensembl: ENSRNOG00000009768], dog [Ensembl: ENSCAFG00000002801] and human [Ensemble: ENSG00000122585]. Comparative sequence analysis revealed highly conserved sequences among the mammalian species with $100 \%$ homology in a GC rich (GGGGCGGG) region and an AT rich (ATAAAA) region. These two regions most likely represent the GC box and TATA box components of the core promoter of the mammalian NPY gene.

However, a discrepancy was identified in the naming of the exons. Exon 1 of the horse, mouse and human, corresponded to a section of the 5' untranslated region (UTR) in the bovine sequence. The first exon reported in the
NCBI bovine sequence was 1056 nucleotides (nt) downstream from the TATA box. As the core promoter sequence (TATA box) of a typical TATA driven mammalian gene is generally located about 26 to $31 \mathrm{nt}$ upstream of the TSS [21], we sought to verify the presence of an additional currently unidentified exon containing the TSS in the bovine.

\section{Identification of exon I and the TSS of the bovine NPY gene}

Analysis of the sequence data from full length cDNA [GeneBank: EU935419] from the arcuate nucleus, cerebral, and cerebellar regions of the brain revealed that the TSS of the bovine NPY gene (comprised of an ACC site) was located 29 nt downstream of the ATAAAA motif (relative to the T). Identification of the TSS confirms that a previously unidentified exon is present in the bovine NPY gene. Comparative sequence analysis of full length cDNA with the NCBI available DNA sequences from the horse, mouse, rat, dog and human identified this exon (99 nt length) as exon 1 in the bovine (Figure 1). This confirms that the bovine NPY gene consists of four exons (total cDNA length $563 \mathrm{nt}$ ) and three introns (Figure 2).

Variation in the expression of NPY gene in different tissues The expression of the bovine NPY gene was investigated in the arcuate nucleus, cerebral and cerebellar regions of the brain, subcutaneous adipose tissue, Longissimus dorsi muscle, liver and small intestine. As demonstrated by the qualitative gene expression analysis by RT-PCR, the mRNA of the bovine NPY gene was present in the arcuate nucleus, cerebral and cerebellar regions of the brain, subcutaneous adipose tissue, $L$. dorsi muscle and small intestine and absent in the liver (data not shown). However, the quantitative real time RT-PCR revealed that the relative abundance of the NPY gene transcript (normalized against the GAPDH gene), were high in the brain tissues, low in the subcutaneous adipose tissue and small intestine and negligible in the L. dorsi muscle (Figure 3).

\section{SNPs in the promoter region of the bovine NPY gene}

The SNPs identified were positioned based on the identification of the TSS. Nine SNPs were identified in a $639 \mathrm{nt}$ segment of the promoter region of the bovine NPY gene (Table 1). The nucleotide diversity in this region was calculated to be $2.84 \times 10^{-3}$. Of these SNPs, four $(-20,-122$, 124 and -347$)$ were unique to $B$. taurus and one $(-31)$ was unique to $B$. indicus. Four SNPs $(-190,-257,-324$ and $520)$ were common to both species. At loci -257 and -190 , $A$ and $T$ were the major alleles in $B$. taurus whereas in these two loci $C$ was the major allele in $B$. indicus. Two $C$ insertions, at -122 and -124 were present in one Limousin animal. Using EM algorithm a total of 15 haplotypes were identified from the pooled datasets from B. taurus and $B$. indicus samples and the haplotypes diversity presented (Figure 4). 


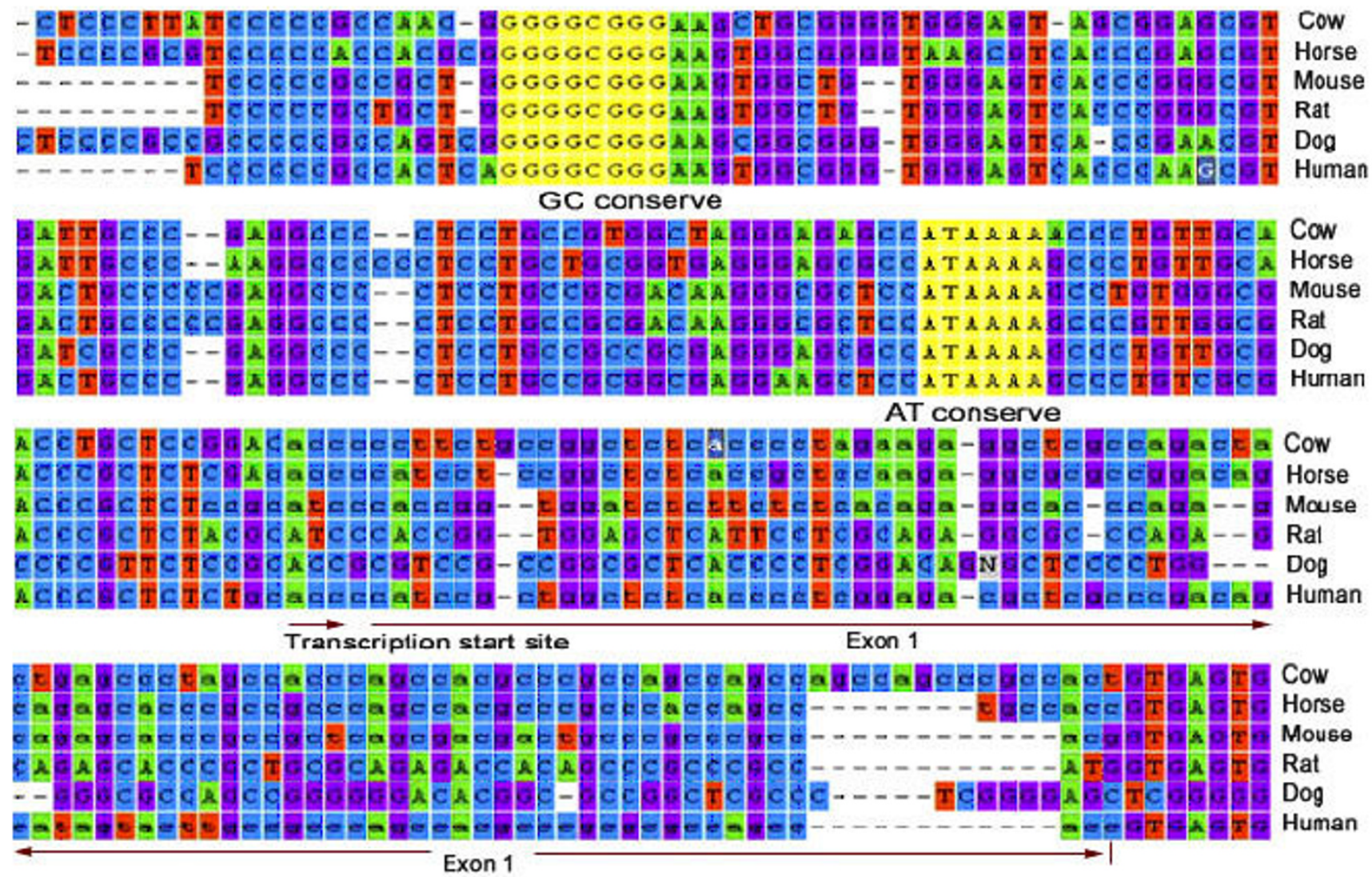

Figure I

Comparative sequence analyses of the promoter region of the NPY gene in mammalian species. The conserved TATA and GC boxes (highlighted in yellow), transcription start sites and the available exon I (in lower case) are shown.

The promoter sequence of the bovine NPY gene was screened for the identification of different putative transcription factor binding sites (TFBS). In the 639 nt promoter region examined, a total of 61 TFBS bindings were predicted (core similarity $>80 \%$ and matrix similarity $>85 \%$, both strands) which included TFBS from 51 different transcription factor families (data not shown). SNPs at loci $-20,-31,-122,-124,-257,-324$ and -347 affect 15 putative TFBS (Table 2). Of the total 9 SNPs identified in the promoter region of the bovine NPY gene, the SNPs at -20 and -31 are very interesting since they are present in the core promoter region (TATA box). These two SNPs are most likely to affect the binding of the TATA-binding protein factor and autoimmune regulatory element binding factor.

\section{SNPs in the exonic, intronic and 3' UTR of the bovine NPY gene}

In the $563 \mathrm{nt}$ exonic region (total 4 exons) of the bovine NPY gene, a total of four SNPs were identified (Table 3). The nucleotide diversity in the exonic regions was calculated to be $1.44 \times 10^{-3}$. The SNPs at +1100 (B. taurus) and
+1106 (B. indicus) were present in exon 2. However, as deduced from the amino acid sequence of the NPY peptide, no amino acid changes occur due to any of these SNPs. Two exonic SNPs were also present at +6751 (B. taurus) and +6887 (B. indicus) in exon 4 . These variants are located in the untranslated region of the mRNA transcript which might have regulatory role.

A total of forty one SNPs were identified in the $6358 \mathrm{nt}$ region across the three introns (Table 3). Thirteen SNPs were identified in intron 1 (929 nt), fifteen in intron 2 (3638 nt) and thirteen in intron 3 (1790 nt). The overall nucleotide diversity in the intronic regions was $1.30 \times 10^{-}$ 3. A total of five SNPs were also identified in the 3 ' UTR (801 nt) of the bovine NPY gene (Table 3 ) which gave rise to a nucleotide diversity value of $1.26 \times 10^{-3}$.

\section{Discussion}

Following a combined approach of full length cDNA analyses, genomic DNA sequencing and evolutionary genomics, we characterised the bovine NPY gene transcript. We identified one previously unidentified exon of the bovine 


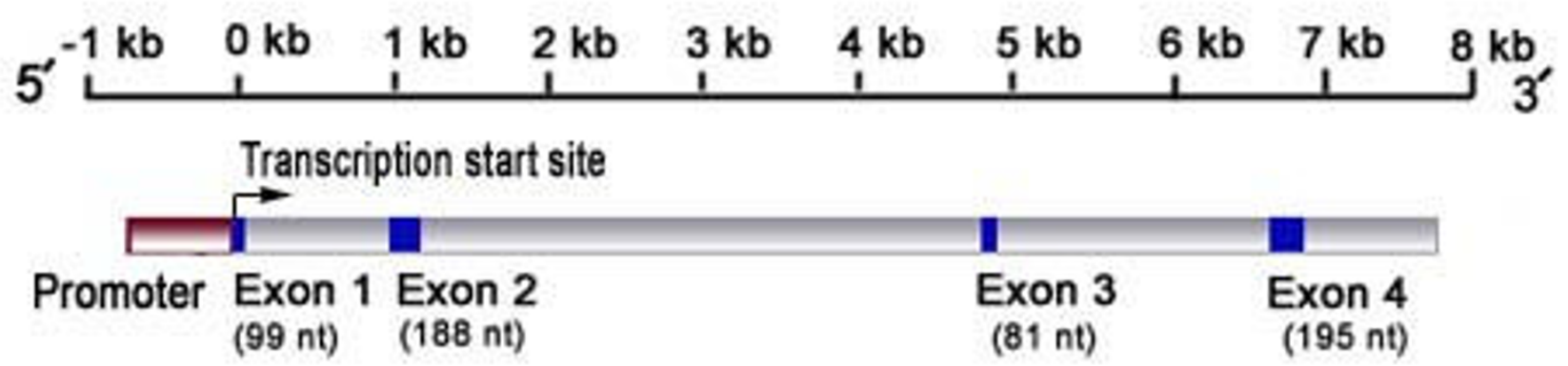

$\begin{array}{lrl}\text { Exon1: } & 1 \text { to } 99 & \text { Exon3: } 4855 \text { to } 4935 \\ \text { Intron: } 100 \text { to } 1028 & \text { Intron: } 4936 \text { to } 6725 \\ \text { Exon2: } 1029 \text { to } 1216 & \text { Exon4: } 6726 \text { to } 6920 \\ \text { Intron: } 1217 \text { to } 4854 & \end{array}$

\section{Bovine NPY gene}

Figure 2

Schematic diagram of the bovine NPY gene showing the promoter, exons, introns and 3' regions and their relative sizes and positions reference to the TSS.

NPY gene and mapped the TSS and various coding and non-coding regions of the NPY gene transcript. Analyses of the tissue specific expression of the bovine NPY gene revealed the presence of highly abundant NPY gene transcripts in the arcuate nucleus, cerebral and cerebellar regions of the bovine brain. We sequenced a total of 8361 nt genomic region which included the coding and noncoding regions of the gene and identified a total of 59 SNPs. A high level of nucleotide diversity was evident in the promoter region compared to the exonic, intronic and 3' UTR.

Based on the in silico analyses of the NPY gene sequences from horse, mouse, rat, dog and human, we identified the core promoter of the bovine NPY gene. Our results suggested that the conserved ATAAAA region of the NPY gene is the TATA element. The TATA element serves as a binding site for the TATA binding protein (TBP), an important transcription factor which plays a key role in the transcriptional activity of the RNA polymerase II enzyme [21,22]. We also identified another interesting conserved GC rich region (GGGGCGGG) as the GC box element of the NPY promoter. The mammalian GC box element is the TFBS of SP1 which initiates transcription [23-25]. The TATA and the GC elements are separated from the TSS by $29 \mathrm{nt}$ and $\sim 100 \mathrm{nt}$, respectively, which is typical for any TATA containing mammalian gene [21]. The previously reported TATA elements of the NPY gene of chicken (TTAAAA) [14] and Chinese perch (ATAAAA) [26] were very similar to the TATA element of the mammals identified in this experiment. The TSS of the bovine NPY gene (ACC) is similar to the previously characterised TSS of the human [27].

We identified an extra exon of the bovine NPY gene (99 nt length) which was previously uncharacterized. In the $\mathrm{NCBI}$ /Ensemble databases, this exon was designated in the horse, mouse and human NPY gene sequences. This exon is located outside the region that translates into the core peptide of 36 amino acids. As in most eukaryotic genes, the region corresponding to the first exon in the mRNA transcript is likely to play a regulatory role in the translation of the NPY mRNA [28]. The first exon provides the initial binding site for the 40S ribosomal unit which is required to start the translation at an AUG codon of the reading frame [28]. To have an efficient translation at the AUG codon, the first exon must have an A at three nt upstream of the AUG codon [28,29]. This A was highly conserved across the mammalian species investigated in this experiment. The length of the bovine NPY cDNA deduced (563 nt, excluding the poly A tail) is in agreement with the previously reported NPY cDNA length of the human (591 nt, which included the poly A tail) [27].

A high level of expression of the NPY gene was evident in the arcuate nucleus, cerebral and cerebellar regions of the brain. As previously demonstrated in the mammalian 


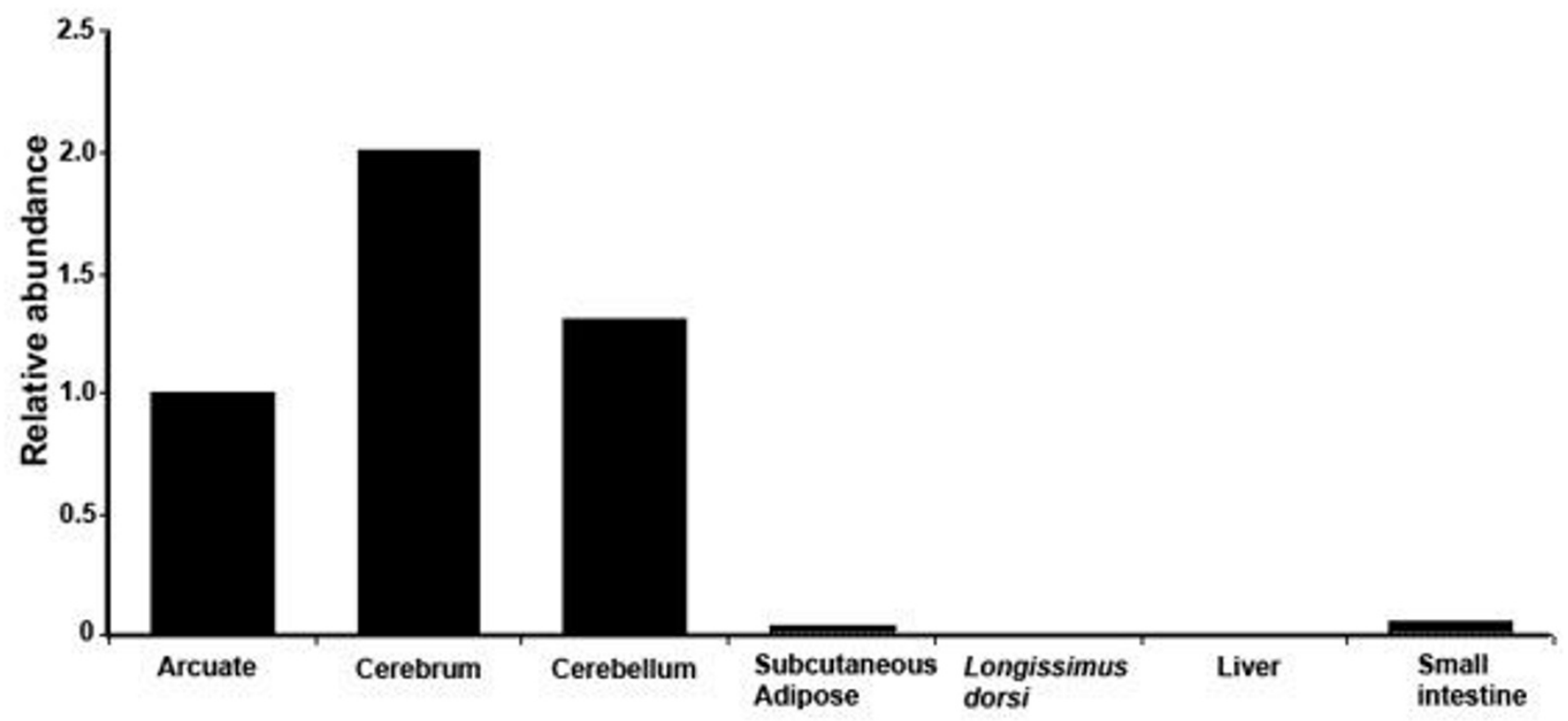

Figure 3

Relative abundance of bovine NPY gene transcript in the arcuate, cerebrum and cerebellum regions of the brain, subcutaneous adipose tissue, Longissimus dorsi, liver and small intestine tissues. The mRNA transcripts of bovine NPY and GAPDH genes were quantified by the real time reverse transcriptase PCR. The relative quantities of the mRNA transcript of bovine NPY gene were normalized against the relative quantities of the GAPDH (housekeeping) gene.

brain, Neuropeptide $Y$ is widely distributed in the central nervous system of mammals [30,31]. The availability of the NPY mRNA transcript in the central nervous system suggests its central regulation of energy homeostasis. Among the peripheral tissues, expression of the NPY gene was also evident in the subcutaneous adipose tissue and small intestine. Since both subcutaneous adipose tissue and the mammalian gastrointestinal tract are innervated, such tissues can also produce neuropeptide Y [26,32]. Recently, mammalian adipose tissue has been identified as a new site of NPY gene expression and neuropeptide Y biosynthesis $[33,34]$. The neuropeptide Y produced in the brain and that of the peripheral tissue system such as adipose tissues had structural similarity. However, the functional relevance of neuropeptide $\mathrm{Y}$ in these tissues needs more research. Although we did not detect any NPY gene transcript in the liver tissue and a minor expression the $L$. dorsi, availability of neuropeptide $\mathrm{Y}$ in the mammalian skeletal muscle tissue and liver has been previously reported in the literature [35-37].

We sequenced a 639 nt promoter region and identified nine novel SNPs of which seven SNPs were affecting TFBS. Interestingly, the SNPs at -20 ( $\mathrm{T}$ to $\mathrm{G}$ transversion) and -

Table I: Single nucleotide polymorphisms (SNPs) identified in the promoter region of bovine NPY gene and their population statistics.

\begin{tabular}{|c|c|c|c|c|c|c|}
\hline \multirow[t]{2}{*}{ NCBI dbSNP Accession ss\# } & \multirow[t]{2}{*}{ Locus } & \multirow[t]{2}{*}{ SNP } & \multicolumn{2}{|c|}{ Bos taurus $(n=34)$} & \multicolumn{2}{|c|}{ Bos indicus $(n=6)$} \\
\hline & & & Major allele frequency & Heterozygous & Major allele frequency & Heterozygous \\
\hline 107795824 & -520 & $\mathrm{C} / \mathrm{A}$ & $0.85(\mathrm{C})$ & 9 & $0.50(\mathrm{C})$ & 0 \\
\hline 107795825 & -347 & $\mathrm{~A} / \mathrm{T}$ & $0.97(\mathrm{~A})$ & 0 & - & - \\
\hline 107795826 & -324 & $\mathrm{C} / \mathrm{A}$ & $0.97(\mathrm{C})$ & 2 & $0.50(\mathrm{C})$ & 1 \\
\hline 107795827 & -257 & $\mathrm{~A} / \mathrm{C}$ & $0.95(\mathrm{~A})$ & 1 & $0.90(\mathrm{C})$ & 1 \\
\hline 107795828 & -190 & $\mathrm{~T} / \mathrm{C}$ & $0.95(\mathrm{~T})$ & 1 & $0.90(\mathrm{C})$ & I \\
\hline 107795829 & -124 & $\mathrm{C} /+$ & $0.97(\mathrm{C})$ & 0 & - & - \\
\hline 107795830 & -122 & $\mathrm{C} /+$ & $0.97(\mathrm{C})$ & 0 & - & - \\
\hline |0779583| & -31 & $\mathrm{C} /+$ & - & - & $0.83(\mathrm{C})$ & 0 \\
\hline 107795832 & -20 & $\mathrm{~T} / \mathrm{G}$ & $0.93(\mathrm{~T})$ & 1 & - & - \\
\hline
\end{tabular}




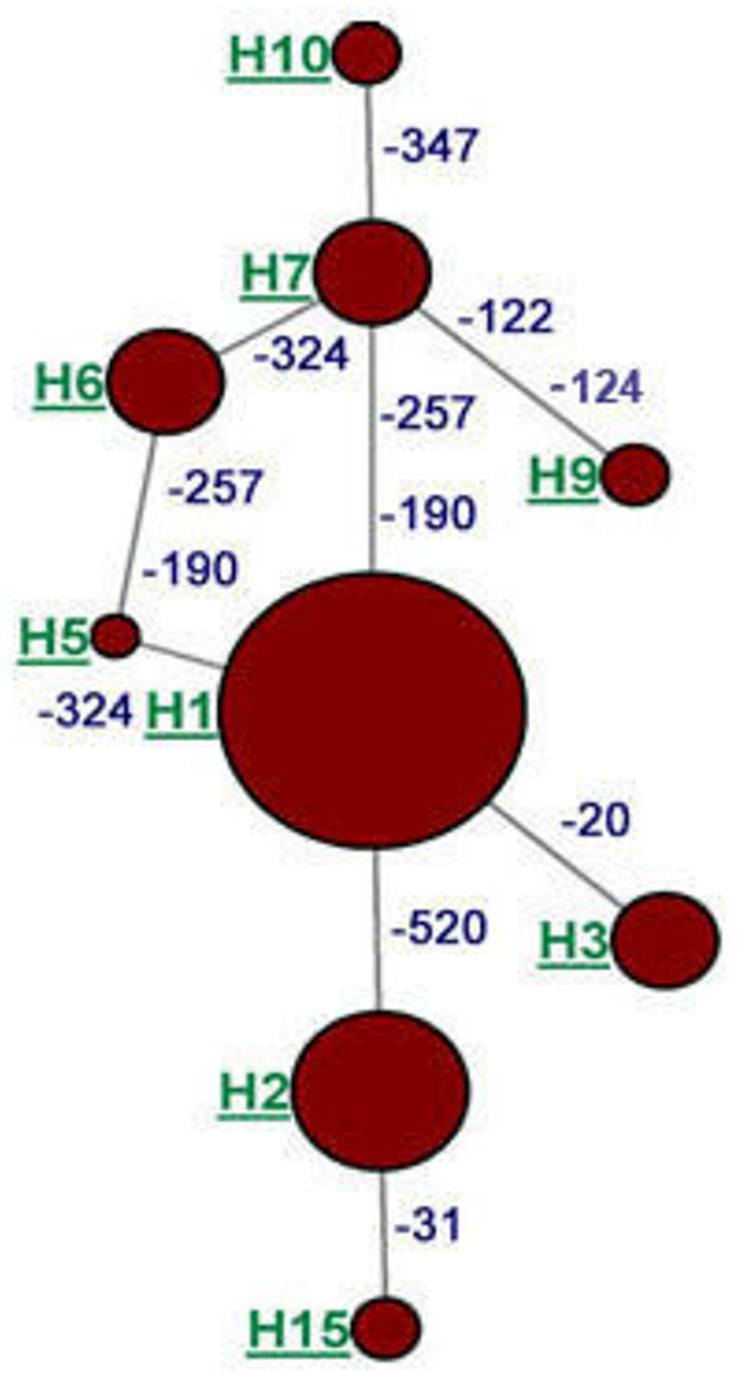

Figure 4

Diversity of the haplotypes based on the occurrence of SNPs in the promoter region of the NPY gene in the Bos taurus and $B$. indicus cattle. The major haplotypes $(\mathrm{HI}, \mathrm{H} 2, \mathrm{H} 3, \mathrm{H} 5, \mathrm{H} 6, \mathrm{H} 7, \mathrm{H}$, $\mathrm{HIO}$ and $\mathrm{HI} 5)$ are indicated by the circle proportional to the haplotype frequency and separated by the SNP loci differing between the haplotypes.

31 (C addition) are on the TFBS of the TATA binding protein (TBP) transcription factor. The TATA box of the NPY gene constitutes the core promoter region which is highly conserved across the mammalian species and hence, the SNPs at -20 and -31 are likely to play vital roles in the expression of the bovine NPY gene. Other mutations identified in the promoter region of the bovine NPY gene are also likely to affect the expression of the gene and consequently the amount of Neuropeptide Y synthesised. It has potential consequences for feed energy conversion and energy homeostasis in the bovine $[38,39]$. The haplotypes derived from the SNPs in the promoter region of the bovine NPY gene will serve as a basis for developing in vitro assays for investigating the role of the promoter SNPs in the regulation of the expression of the bovine NPY gene.

Among the four exonic SNPs reported, two exonic SNPs are synonymous and the other two SNPs located in the untranslated region might have a mostly regulatory function which needs further investigation. Among the total 59 SNPs identified in the coding and non-coding regions of the bovine NPY gene, three intronic SNPs $(+1312$, +1694 and +4066 ) were previously reported [13] and the genetic association of two of these SNPs were recently investigated in beef cattle [5].

Noticeably high nucleotide diversity in the promoter region compared to the exonic, intronic and 3' (UTR) regions of the bovine NPY gene observed could serve as a source of genetic variation necessary for the evolutionary adaptation of animals [40]. Since neuropeptide Y is highly conserved during the evolutionary processes, SNPs causing any alteration of the core peptide is probably undesirable [15]. Therefore, the promoter region of the gene is likely to contain more genetic variation for evolutionary adaptation compared to the other regions $[15,41]$. Although most of the SNPs identified were in the intronic regions, the overall nucleotide diversity in the introns was less than that of the promoter region.

\section{Conclusion}

Characterization of the gene transcript, especially identification of the correct promoter region (cis acting element) and TSS, is a requisite for understanding the regulation of gene expression and underlying effects of genetic variation [16]. We systematically characterized the bovine NPY gene transcripts and mapped the promoter, TSS and the exons and intron regions. This will serve as a basis for investigating the regulatory role of the SNPs in the expression of the bovine NPY gene and identification of genotypes with high feed energy conversion efficiency. The extra exon reported may likely play an important role as a regulatory sequence of gene expression [16]. The SNPs and the haplotypes identified in the bovine NPY gene could be targeted for further functional verification and investigating their association with feed intake in cattle in particular, and understanding the physiological role played by the neuropeptide $\mathrm{Y}$ in energy homeostasis in mammals, in general.

\section{Methods}

\section{Tissue samples and RNA extraction}

Tissue samples ( $2 \mathrm{~g}$ each) from bovine brain (arcuate nucleus, cerebral and cerebellar regions), subcutaneous adipose tissue, Longissimus dorsi muscle, liver and small 
Table 2: The SNPs in the $639 \mathrm{nt}$ promoter region of bovine NPY gene those affects the putative transcription factors

\begin{tabular}{|c|c|c|c|c|}
\hline Putative transcription factors & Start & End & Recognition sequence & SNPs \\
\hline PAX-4/PAX-6 paired domain binding sites & -356 & -338 & gagataggtGCAGcccaga* & $\mathrm{A} / \mathrm{T}(-347)$ \\
\hline GATA binding factors & -348 & -336 & cagaGATAggtgc* & $\mathrm{A} / \mathrm{T}(-347)$ \\
\hline Nuclear factor I & -341 & -321 & ccggtctagtcctGCCAgaga* & C/A $(-324)$ \\
\hline Vertebrate SMAD family of transcription factors & -331 & -323 & gGTCTagtc* & C/A $(-324)$ \\
\hline E-box binding factors & -324 & -312 & cctCCACgcccgg* & C/A $(-324)$ \\
\hline Nuclear receptor subfamily 2 factors & -280 & -256 & tggaccacgcCAAAgcacaagtttc* & $A / C(-257)$ \\
\hline EGR/nerve growth factor induced protein C \& related factors & -135 & -119 & aagggAGGGggtccaga* & $+C(-122),+C(-124)$ \\
\hline EGR/nerve growth factor induced protein C \& related factors & -133 & -117 & ataaGGGAgggggtcca* & $+C(-122),+C(-124)$ \\
\hline Pleomorphic adenoma gene & -132 & -112 & GGGGgataagggagggggtcc* & $+C(-122),+C(-124)$ \\
\hline Myc associated zinc fingers & $-|3|$ & -119 & aagggaGGGGgtc* & $+C(-122),+C(-124)$ \\
\hline GC-Box factors SPI/GC & $-|3|$ & -117 & ataagGGAGggggtc* & $+C(-122),+C(-124)$ \\
\hline Gut-enriched Krueppel like binding factor & -128 & -116 & gataagggaGGGG* & $+C(-122),+C(-124)$ \\
\hline GATA binding factors & -124 & -112 & ggggGATAaggga* & $+C(-124)$ \\
\hline Autoimmune regulatory element binding factor & -38 & -12 & ttgcaacagggtttttaTGGCtctccc* & $+C(-31), T / G(-20)$ \\
\hline Tata-binding protein factor & -33 & -17 & agccaTAAAaaccctgt & $+C(-31), T / G(-20)$ \\
\hline
\end{tabular}

*- minus strand

intestine were surgically removed and collected in RNA later $^{\mathrm{TM}}$ (Ambion, Inc. Austin, TX). Total RNA was extracted from $50 \mathrm{mg}$ of the bovine tissue using TRI Reagent ${ }^{\oplus}$ (Molecular Research Centre, Inc. USA) according to the manufacturer's instructions. The RNA was dissolved in 20 $\mu \mathrm{l}$ of $0.1 \%$ DEPC treated water and then subjected to deoxyribonuclease I (DNase I) treatment (Qiagen, Chatsworth, CA, USA). Re-extraction of RNA was carried out using phenol-chloroform. The RNA pellet was finally dissolved in $20 \mu \mathrm{l}$ of nuclease-free water. The quality and quantity of the total RNA was evaluated on a $1.2 \%$ agarose gel stained with ethidium bromide and on a NanoDrop ${ }^{\circledast}$ ND-1000 Spectrophotometer (Thermo Fisher Scientific Inc. MA, USA), respectively. Samples with a 260/280 ratio $\geq 2.0$ were used for further analysis.

\section{Quantitative real time RT-PCR (qRT-PCR)}

Initially the cDNA was synthesized using oligo $(\mathrm{dT})_{20}$ primer with $1.0 \mu \mathrm{g}$ of total RNA in a final reaction volume of $20 \mu \mathrm{l}$ using the Superscript ${ }^{\mathrm{TM}}$ III First-strand synthesis system for reverse transcriptase-polymerase chain reaction (RT-PCR) (Invitrogen Corp., San Diego, CA, USA). Using gene specific primers for the bovine NPY gene [GeneBank: AY491054] (Forward - 5' CGG CTC TCA CCC CTA GAA 3', reverse - 5' TCT GCC TGG TGA TGA GAT 3') and bovine GAPDH gene [42], the qRT-PCR assay was performed in an ABI 7300 Real-Time PCR system (Applied Biosystems, Foster City, CA, USA). The reaction was carried out with $0.5 \mu \mathrm{l}$ cDNA in a $25 \mu \mathrm{l}$ final reaction volume with $1 \times$ Power SYBR $^{\circledast}$ Green master mix (Applied Biosystems) and $0.2 \mu \mathrm{M}$ of each of the forward and reverse primers. The thermal cycle conditions were $94^{\circ} \mathrm{C}$ for $30 \mathrm{sec}$ followed by $60^{\circ} \mathrm{C}$ for $1 \mathrm{~min}$, for 40 cycles, followed by dissociation of the product at $96^{\circ} \mathrm{C}$ for $2 \mathrm{~min}$. The relative quantities of the NPY gene transcript in different bovine tissues were normalized against the relative quantities of the GAPDH gene in those tissues as previously described [42].

\section{Full length cDNA synthesis and amplification of the $5^{\prime}$ and 3' cDNA regions}

Full length cDNA was synthesized from $2.5 \mu \mathrm{g}$ total RNA using a GeneRacer ${ }^{\mathrm{TM}}$ Kit (Invitrogen Corp.) and following manufacturer's instructions. Briefly, the total RNA was dephosphorylated using $10 \mathrm{U}$ of calf intestinal phosphatase and followed by removal of the mRNA cap structure by treating with $0.5 \mathrm{U}$ tobacco acid pyrophosphatase enzyme. At the final step of RNA modification, an RNA oligonucleotide adaptor (5' CGA CUG GAG CAC GAG GAC ACU GAC AUG GAC UGA AGG AGU AGA AA 3') was ligated to the decapped mRNA using $5 \mathrm{U}$ of T4 RNA ligase. Every step of RNA modification was followed by a clean-up step using phenol:chloroform. Full length cDNA was synthesized from the modified RNA using Superscript $^{\mathrm{TM}}$ III First-strand synthesis system as described earlier. However, instead of the conventional oligo $(\mathrm{dT})_{20}$ primer used before, GeneRacer Oligo dT primer which has an anchor sequence (5' GCT GTC AAC GAT ACG CTA CGT AAC GGC ATG ACA GTG 3') with the oligo (dT) ${ }_{24}$ was used.

Amplifications of the 5' end of the NPY gene transcript (5' RACE) were carried out using a combination of the $5^{\prime}$ adaptor primer (5' GGA CAC TGA CAT GGA CTG AAG GAG TA 3') as a forward primer and a gene specific primer (sequence as above) as reverse primer. For the amplification of the 3' end (3' RACE), the gene specific forward primer (sequence as above) and $3^{\prime}$ adaptor primer (5' CGC TAC GTA ACG GCA TGA CAG TG 3') were used. The PCR conditions for both $5^{\prime}$ and $3^{\prime}$ RACE-PCR were; $94^{\circ} \mathrm{C}$ for $2 \mathrm{~min}$ followed by forty cycles of denaturation $\left(94^{\circ} \mathrm{C}\right.$ for $30 \mathrm{sec})$, annealing $\left(57^{\circ} \mathrm{C}\right.$ for $\left.30 \mathrm{sec}\right)$ and amplification 
Table 3: Single nucleotide polymorphisms (SNPs) in the exonic (in bold letters), intronic and 3' regions of bovine neuropeptide $Y$ (NPY) gene.

\begin{tabular}{|c|c|c|c|c|c|c|}
\hline \multirow[t]{2}{*}{ NCBI dbSNP Accession ss\# } & \multirow[t]{2}{*}{ Locus } & \multirow[t]{2}{*}{ SNP } & \multicolumn{2}{|c|}{ Bos taurus $(n=34)$} & \multicolumn{2}{|c|}{ B. indicus $(n=6)$} \\
\hline & & & Major allele frequency & Heterozygous & Major allele frequency & Heterozygous \\
\hline 107795833 & 197 & $\mathrm{C} / \mathrm{G}$ & - & - & 0.83 & 0 \\
\hline 107795834 & 218 & $\mathrm{G} / \mathrm{C}$ & 0.91 & 0 & 0.83 & 0 \\
\hline 107795835 & 228 & $\mathrm{C} / \mathrm{T}$ & 0.99 & 1 & 0.67 & 4 \\
\hline 107795836 & 305 & $\mathrm{C} / \mathrm{G}$ & 0.93 & 3 & 0.92 & 1 \\
\hline 107795837 & 358 & $\mathrm{G} / \mathrm{A}$ & 0.99 & 1 & 0.75 & 3 \\
\hline 107795838 & 361 & $\mathrm{~A} / \mathrm{C}$ & 0.93 & 3 & 0.92 & 1 \\
\hline 107795839 & 380 & $\mathrm{G} / \mathrm{A}$ & - & - & 0.67 & 4 \\
\hline 107795840 & 592 & $\mathrm{C} / \mathrm{A}$ & 0.99 & I & 0.67 & 2 \\
\hline |0779584| & 642 & $\mathrm{G} / \mathrm{A}$ & 0.93 & 3 & 0.88 & 1 \\
\hline 107795842 & 762 & $\mathrm{~T} / \mathrm{C}$ & 0.96 & I & 0.92 & 1 \\
\hline 107795843 & 820 & $\mathrm{G} / \mathrm{A}$ & 0.97 & 0 & - & - \\
\hline 107795844 & 1004 & $\mathrm{C} /+$ & - & - & 0.83 & 0 \\
\hline 107795845 & 1014 & $\mathrm{C} / \mathrm{T}$ & 0.97 & 2 & 0.83 & 0 \\
\hline 107795846 & 1100 & $C / T$ & 0.99 & I & - & - \\
\hline 107795847 & 1106 & C/G & - & - & 0.90 & I \\
\hline 107795848 & 1312 & $\mathrm{~A} / \mathrm{C}$ & 0.75 & 9 & - & - \\
\hline 107795849 & $|32|$ & $\mathrm{A} / \mathrm{G}$ & 0.87 & 5 & - & - \\
\hline 107795850 & 1420 & $\mathrm{C} / \mathrm{A}$ & - & - & 0.90 & 1 \\
\hline |0779585| & $|54|$ & $\mathrm{G} / \mathrm{A}$ & - & - & 0.80 & 2 \\
\hline 107795852 & 1694 & $\mathrm{~A} / \mathrm{G}$ & 0.57 & 11 & - & - \\
\hline 107795853 & 1713 & $\mathrm{G} / \mathrm{T}$ & 0.85 & 4 & - & - \\
\hline 107795854 & 1757 & $\mathrm{G} / \mathrm{A}$ & - & - & 0.80 & 2 \\
\hline 107795855 & 1865 & $\mathrm{~T} / \mathrm{C}$ & 0.93 & 3 & - & - \\
\hline 107795856 & 2175 & $\mathrm{C} / \mathrm{T}$ & 0.91 & 4 & - & \\
\hline 107795857 & 2551 & $\mathrm{~A} /-$ & - & - & - & - \\
\hline 107795858 & 2892 & $\mathrm{G} / \mathrm{A}$ & 0.70 & 14 & - & - \\
\hline 107795859 & 3883 & $\mathrm{~A} /-$ & - & - & - & - \\
\hline 107795860 & 4018 & $\mathrm{G} / \mathrm{A}$ & 0.97 & 0 & - & - \\
\hline | $0779586 \mid$ & 4042 & $\mathrm{G} / \mathrm{A}$ & - & - & 0.80 & 2 \\
\hline 107795862 & 4066 & $\mathrm{~T} / \mathrm{C}$ & 0.75 & 9 & - & - \\
\hline 107795863 & 4953 & $\mathrm{G} / \mathrm{A}$ & 0.96 & 3 & - & - \\
\hline 107795864 & 5213 & $C / G$ & 0.96 & 3 & - & - \\
\hline 107795865 & 5273 & $\mathrm{~A} / \mathrm{G}$ & 0.96 & 3 & - & - \\
\hline 107795866 & 5280 & $\mathrm{~T} / \mathrm{A}$ & 0.96 & 3 & - & - \\
\hline 107795867 & 5642 & $\mathrm{C} / \mathrm{T}$ & 0.95 & 3 & 0.75 & 1 \\
\hline 107795868 & 5930 & $\mathrm{~A} / \mathrm{G}$ & - & - & 0.83 & 2 \\
\hline 107795869 & 6341 & $\mathrm{G} / \mathrm{A}$ & - & - & 0.50 & 4 \\
\hline 107795870 & 6368 & $\mathrm{~T} / \mathrm{G}$ & 0.95 & 3 & 0.75 & I \\
\hline |0779587| & 6385 & $\mathrm{~A} / \mathrm{G}$ & 0.95 & 3 & 0.75 & 1 \\
\hline 107795872 & 6400 & $\mathrm{C} / \mathrm{T}$ & 0.95 & 3 & 0.75 & 1 \\
\hline 107795873 & 6526 & $\mathrm{~A} / \mathrm{T}$ & 0.98 & 1 & - & - \\
\hline 107795874 & 6527 & $\mathrm{G} / \mathrm{A}$ & 0.95 & 3 & - & - \\
\hline 107795875 & 6658 & $\mathrm{~A} / \mathrm{C}$ & 0.91 & 4 & 0.83 & 2 \\
\hline 107795876 & 6751 & $\mathbf{T} / \mathbf{G}$ & 0.99 & $\mathbf{I}$ & - & \\
\hline 107795877 & 6887 & $\mathbf{A} / \mathbf{T}$ & - & - & 0.83 & 2 \\
\hline 107795878 & 7192 & $\mathrm{C} / \mathrm{T}$ & 0.50 & 16 & - & - \\
\hline 107795879 & 7211 & $\mathrm{~A} / \mathrm{T}$ & 0.91 & 4 & - & - \\
\hline 107795880 & 7552 & T/- & 0.88 & 0 & 0.80 & 0 \\
\hline |0779588| & 7553 & $\mathrm{C} /-$ & 0.88 & 0 & 0.80 & 0 \\
\hline 107795882 & 7641 & $\mathrm{~T} / \mathrm{G}$ & 0.88 & 2 & - & - \\
\hline
\end{tabular}


$\left(70^{\circ} \mathrm{C}\right.$ for $\left.1 \mathrm{~min} 30 \mathrm{sec}\right)$. The PCR products were assayed on a $1.2 \%$ agarose gel. The PCR product of the $5^{\prime}$ and $3^{\prime}$ RACE-PCR were cloned into a plasmid vector using TOPO TA cloning ${ }^{\circledR}$ kit (Invitrogen Corp.) following the manufacturer's instructions. Sequencing of the plasmid DNA was carried out in both forward and reverse directions as described below.

\section{Identification of SNPs in the bovine NPY gene} Animals and genomic DNA preparation

The animals (total $n=40$ ) used for identification of the SNPs in the bovine NPY gene comprised of unrelated pedigree bulls ( $\mathrm{n}=34$ ) used for performance evaluation by the Irish Cattle Breeding Federation (ICBF) at the National Beef Performance Station (NBPS), Tully, Co. Kildare, Ireland and one breed of $B$. indicus $(n=6)$ (Table 4). Blood samples were collected from the jugular vein of the cattle in BD Vacutainers (Vacutainer Systems, UK) and stored at $-20^{\circ} \mathrm{C}$ until used for DNA extraction. Genomic DNA was extracted from $200 \mu$ l of blood using GenElute $e^{\mathrm{TM}}$ Blood Genomic DNA kit (Sigma-Aldrich Corp. St. Louis, $\mathrm{MO}$, USA) following manufacturer's instructions. At the final step, the genomic DNA was eluted with $200 \mu$ nuclease free water and store at $-20^{\circ} \mathrm{C}$. The quality and quantity of the genomic DNA was assessed on a $0.8 \%$ agarose gel and using a NanoDrop ${ }^{\circledR}$ N-1000 Spectrophotometer (Thermo Fisher Scientific Inc.), respectively.

PCR amplification of the genomic region of the bovine NPY gene The nucleotide sequence of the bovine NPY gene (including the 5'and 3' UTR) was obtained from the GeneBank through alignment of the contig [GeneBank: NC 007302.1] with the available bovine NPY gene sequence [GeneBank: AY491054]. Seven sets of PCR

Table 4: Breeds of beef cattle used for determination of the diversity of SNPs in the coding and non-coding region of bovine NPY gene

\begin{tabular}{|c|c|c|}
\hline Species & Breed & (n) \\
\hline \multirow[t]{12}{*}{ Bos taurus } & & 34 \\
\hline & Limousin & 6 \\
\hline & Simmental & 6 \\
\hline & Charolais & 5 \\
\hline & Aberdeen Angus & 4 \\
\hline & Hereford & 3 \\
\hline & Parthenais & 3 \\
\hline & Salers & 3 \\
\hline & Aubrac & I \\
\hline & Belgian Blue & i \\
\hline & Blonde d'Aquitaine & I \\
\hline & Shorthorn & I \\
\hline \multirow[t]{2}{*}{ Bos indicus } & Local breeds & 6 \\
\hline & Total & 40 \\
\hline
\end{tabular}

primers (Table 5) were generated using the web-based software Primer3 http://primer3.sourceforge.net/ to amplify a total of $8361 \mathrm{nt}$ genomic region. The primers were designed in such a way as to provide an overlap of 100 nt between any two consecutive fragments. PCR amplification of the different fragments of the bovine NPY gene was performed in a PTC-225 DNA Engine Tetrad (MJ Research, Inc. Massachusetts, USA) with $0.75 \mu \mathrm{L}$ of the genomic DNA template in a $50 \mu$ final reaction volume. The PCR reaction contained $1 \times$ PCR buffer, $1.5 \mathrm{mM}$ $\mathrm{MgCl}_{2}, 0.2 \mu \mathrm{M} \mathrm{dNTP} \mathrm{mix}, 0.2 \mu \mathrm{M}$ each of the forward and reverse primers and 0.2 unit of Platinum Taq DNA polymerase (Invitrogen Corp.). The PCR cycle conditions were $94^{\circ} \mathrm{C}$ for $45 \mathrm{sec}, 55^{\circ} \mathrm{C}$ for $45 \mathrm{sec}$ and $72^{\circ} \mathrm{C}$ for 1.5 min for forty cycles followed by a final extension of $72^{\circ} \mathrm{C}$ for $10 \mathrm{~min}$ for all fragments.

\section{Sequencing of the genomic/plasmid DNA}

For sequencing of the PCR products, $40 \mu \mathrm{l}$ of the PCR product was cleaned up using Gen Elute ${ }^{\mathrm{TM}}$ PCR clean-up kit (Sigma-Aldrich Corp.) following the manufacturer's instructions. The quality and quantity of the purified PCR product was assessed as described earlier. Using both forward and reverse primer sets, separate sequencing reactions were performed on the clean PCR product (20 ng/ 100 bases of DNA to be sequenced). For the plasmid DNA, 200 ng of the plasmid DNA was sequenced in both directions using plasmid-specific standard sequencing primers. Sequencing was performed by MWG-Biotech, Germany. Sequence data with PHRED quality score $>20$ (conform the accuracy of $>99 \%$ of the base called) was used for multiple sequence comparison and SNP identification. SNPs were identified through comparison of the sequence data from all animals using Molecular Evolutionary Genetic Analysis (MEGA) v 4.0 software [43].

\section{Statistical Analysis}

The nucleotide diversity in the promoter, exon, intron and 3' (UTR) regions of the bovine NPY gene was calculated considering the normalized number of variant sites as previously described [44,45]. Accordingly, the normalized number of variant sites

$$
\theta=\mathrm{K} / \sum_{\mathrm{i}=1}^{\mathrm{n}-1} \mathrm{i}^{-1} \mathrm{~L}
$$

where, ' $K$ ' is the observed number of variant sites, ' $L$ ' is the total sequence length and ' $n$ ' is the number of chromosome sequenced. Basic population statistics including the allele and genotype frequencies were determined by analysis of the genotype data using Arlequin 3.11 [46]. The haplotype analysis was performed using EM algorithm in the Arlequin software. 
Table 5: The sequences of the oligonuclotides and the size of the corresponding PCR products used for sequencing of different regions of the bovine NPY gene

\begin{tabular}{|c|c|c|}
\hline Primer & Nucleotide sequence & Product size (base) \\
\hline \multirow[t]{2}{*}{ NPO } & For 5'CCAAAACCAAGCTGGGAAAAG 3' & 1427 \\
\hline & Rev 5'GGTCCAGTAGCAGAGCCAAG 3' & \\
\hline \multirow[t]{2}{*}{ NPI } & For 5'GGGCAGACCAAAACTGAAAA 3' & 1252 \\
\hline & Rev 5'CACCAAGTGGGCATTTTCTT 3' & \\
\hline \multirow[t]{2}{*}{ NP2 } & For 5'TGCCCAGACTGAAGTGAAAAG 3' & 1160 \\
\hline & Rev 5'GGAGGGCTCCAATTTAATCAC 3' & \\
\hline \multirow[t]{2}{*}{ NP3 } & For 5'TCCTAGGCATTACTTTGTTCAGTC 3' & 1090 \\
\hline & Rev 5'AGGTACCCAGAGCAGCATCA 3' & \\
\hline \multirow[t]{2}{*}{ NP4 } & For 5'ACCCCCAGGGTGATTCTAAC 3' & 1009 \\
\hline & Rev 5'TGCACATTACTGCTGCTGAA 3' & \\
\hline \multirow[t]{2}{*}{ NP5 } & For 5'TGGACCAGTAGGTTTCCTTCA 3' & 1153 \\
\hline & Rev 5'GCAGGCGTCTTTTCACTTTC 3' & \\
\hline \multirow[t]{2}{*}{ NP6 } & For 5'ACTTGGGGCTTTCTTGGAGT 3' & 1020 \\
\hline & Rev 5'CTTCCAGCCTGTCAAACACA 3' & \\
\hline \multirow[t]{2}{*}{ NP7 } & For 5'CAGCAGCCTTTTCAACAGTTT 3' & 1115 \\
\hline & Rev 5'TGCTACAGGGATTTGGTAAGC 3' & \\
\hline
\end{tabular}

\section{Authors' contributions}

Both authors actively participated in the design of the study and in the writing of the manuscript. BB performed all the experimental steps and TS supervised the SNP analysis.

\section{Acknowledgements}

This research was part funded by the Irish Department of Agriculture, Fisheries and Food. The authors gratefully acknowledge the Irish Cattle Breeding Federation for supplying the blood samples.

\section{References}

I. Moss AR, Jouany JP, Newbold J: Methane production by ruminants: its contribution to global warming. Ann Zootech 2000, 49(3):23I-253.

2. Schiere JB, Ibrahim MNM, van Keulen $\mathrm{H}$ : The role of livestock for sustainability in mixed farming: criteria and scenario studies under varying resource allocation. Agri Ecosys Environ 2002, 90(2): I39-153.

3. Waghorn GC, Woodward SL, Tavendale M, Clark DA: Inconsistencies in rumen methane production - effects of forage composition and animal genotype. Intl Congress Series 2006, 1293:115-118.

4. Hegarty RS, Goopy JP, Herd RM, McCorkell B: Cattle selected for lower residual feed intake have reduced daily methane production. J Anim Sci 2007, 85(6): | 479-I 486

5. Sherman EL, Nkrumah JD, Murdoch BM, Li C, Wang Z, Fu A, Moore SS: Polymorphisms and haplotypes in the bovine NPY, GHR, GHRL, IGF2, UCP2, and UCP3 genes and their associations with measures of growth, performance, feed efficiency and carcass merit in beef cattle. J Anim Sci 2008, 86: I- I6.

6. Tatemoto K, Carlquist M, Mutt V: Neuropeptide $Y$ - a novel brain peptide with structural similarities to peptide $Y Y$ and pancreatic polypeptide. Nature 1982, 296(5858):659-660.

7. Wynne K, Stanley S, McGowan B, Bloom S: Appetite control. J Endocrinol 2005, I 84(2):29|-3।8.

8. Arora $S$, Anubhuti : Role of neuropeptides in appetite regulation and obesity - A review. Neuropeptides 2006, 40(6):375-40I.

9. White JD: Neuropeptide Y: a central regulator of energy homeostasis. Regul Pept 1993, 49(2):93-107.

10. Thomas MG, Gazal OS, Williams GL, Stanko RL, Keisler DH: Injection of neuropeptide $Y$ into the third cerebroventricle differentially influences pituitary secretion of luteinizing hormone and growth hormone in ovariectomized cows. Domest Anim Endocrinol 1999, 16(3):159-169.
II. Chilliard Y, Bonnet M, Delavaud C, Faulconnier Y, Leroux C, Djiane J, Bocquier F: Leptin in ruminants. Gene expression in adipose tissue and mammary gland, and regulation of plasma concentration. Domest Anim Endocrinol 200 I, 2 I (4):27I-295.

12. Bradley RL, Mansfield JPR, Maratos-Flier E: Neuropeptides, including Neuropeptide $\mathbf{Y}$ and Melanocortins, mediate lipolysis in murine adipocytes. Obesity 2005, 13(4):653-66I.

13. Thue TD, Buchanan FC: Linkage mapping of NPY to bovine chromosome 4. Anim Genet 2004, 35:245.

14. Blomqvist AG, Soderberg C, Lundell I, Milner RJ, Larhammar D: Strong evolutionary conservation of Neuropeptide $Y$ : sequences of chicken, goldfish, and torpedo marmorata DNA clones. Proc Natl Acad Sci 1992, 89(6):2350-2354.

15. Nei M: The new mutation theory of phenotypic evolution. Proc Natl Acad Sci 2007, 1 04(30): 12235-12242.

16. Roni V, Carpio R, Wissinger B: Mapping of transcription start sites of human retina expressed genes. BMC Genomics 2007, $8(1): 42$.

17. Dike S, Balija VS, Nascimento LU, Xuan Z, Ou J, Zutavern T, Palmer LE, Hannon G, Zhang MQ, McCombie WR: The mouse genome: experimental examination of gene predictions and transcriptional start sites. Genome Res 2004, I 4( I 2):2424-2429.

18. Frazer KA, Elnitski L, Church DM, Dubchak I, Hardison RC: Crossspecies sequence comparisons: a review of methods and available resources. Genome Res 2003, I3(I):I-12.

19. Trinklein ND, Aldred SJF, Saldanha AJ, Myers RM: Identification and functional analysis of human transcriptional promoters. Genome Res 2003, 13(2):308-312.

20. Wasserman WW, Sandelin A: Applied bioinformatics for the identification of regulatory elements. Nat Rev Genet 2004, 5(4):276-287.

21. Smale ST, Kadonaga JT: The RNA polymerase II core promoter. Ann Rev Biochem 2003, 72(I):449-479.

22. Hahn S: Structure and mechanism of the RNA polymerase II transcription machinery. Nat Struct Mol Biol 2004, I I (5):394-403.

23. Toyoda A, Fukumaki Y, Hattori M, Sakaki Y: Mode of activation of the GC box/Spl-dependent promoter of the human NADHcytochrome b5 reductase-encoding gene. Gene 1995, 164(2):35I-355.

24. Minth $C D$, Dixon JE: Expression of the human neuropeptide $Y$ gene. J Biol Chem 1990, 265(22): 1 2933-12939.

25. Dynan WS, Tjian R: Control of eukaryotic messenger RNA synthesis by sequence-specific DNA-binding proteins. Nature 1985, 316(603I):774-778.

26. Liang XF, Li GZ, Yao W, Cheong LW, Liao WQ: Molecular characterization of neuropeptide $Y$ gene in Chinese perch, an acanthomorph fish. Comp Biochem Physiol B Biochem Mol Biol 2007. I48(I):55-64. 
27. Minth CD, Bloom SR, Polak JM, Dixon JE: Cloning, characterization, and DNA sequence of a human cDNA encoding neuropeptide tyrosine. Proc Natl Acad Sci 1984, 8 I (14):4577-458 I.

28. Kozak M: Initiation of translation in prokaryotes and eukaryotes. Gene 1999, 234(2): 187-208.

29. Osada Y, Saito R, Tomita M: Comparative analysis of base correlations in $\mathbf{5}^{\prime}$ untranslated regions of various species. Gene 2006, 375:80-86.

30. Adrian TE, Allen JM, Bloom SR, Ghatei MA, Rossor MN, Roberts GW, Crow TJ, Tatemoto K, Polak JM: Neuropeptide $\mathbf{Y}$ distribution in human brain. Nature 1983, 306(5943):584-586.

31. Majane EA, Alho H, Kataoka Y, Lee CH, Yang HY: Neuropeptide $Y$ in bovine adrenal glands: distribution and characterization. Endocrinology 1985, I I7(3): I |62-I I 68.

32. Sheikh SP: Neuropeptide $Y$ and peptide YY: major modulators of gastrointestinal blood flow and function. Am J Physiol 1991, 26I(5):G70I-7I5.

33. Yang K, Guan H, Arany E, Hill DJ, Cao X: Neuropeptide $Y$ is produced in visceral adipose tissue and promotes proliferation of adipocyte precursor cells via the YI receptor. FASEB J 2008, 22(7):2452-2464.

34. Kos KH, Harte AL, James S, Snead DR, O'Hare JP, McTernan PG, Kumar S: Secretion of neuropeptide $Y$ in human adipose tissue and its role in maintenance of adipose tissue mass. Am J Physiol Endocrinol Metab 2007, 293(5):EI335-EI 340.

35. Taborsky G] Jr, Beltramini LM, Brown M, Veith RC, Kowalyk S: Canine liver releases neuropeptide $Y$ during sympathetic nerve stimulation. Am J Physiol 1994, 266(5):E804-8I 2.

36. Burt AD, Tiniakos D, MacSween RN, Griffiths MR, Wisse E, Polak JM: Localization of adrenergic and neuropeptide tyrosine-containing nerves in the mammalian liver. Hepatology 1989 9(6):839-845.

37. Pernow J, Schwieler J, Kahan T, Hjemdahl P, Oberle J, Wallin BG, Lundberg JM: Influence of sympathetic discharge pattern on norepinephrine and neuropeptide $\mathbf{Y}$ release. Am J Physiol 1989, 257(3): $\mathrm{H} 866-872$.

38. Hoogendoorn B, Coleman SL, Guy CA, Smith K, Bowen T, Buckland $\mathrm{PR}$, O'Donovan MC: Functional analysis of human promoter polymorphisms. Hum Mol Genet 2003, I 2( I 8):2249-2254

39. Belanger H, Beaulieu P, Moreau C, Labuda D, Hudson TJ, Sinnett D: Functional promoter SNPs in cell cycle checkpoint genes. Hum Mol Genet 2005, I 4(I8):264I-2648.

40. Taylor MS, Kai C, Kawai J, Carninci P, Hayashizaki Y, Semple CA: Heterotachy in mammalian promoter evolution. PLoS Genet 2006, 2(4):e30.

4I. Balhoff JP, Wray GA: Evolutionary analysis of the well characterized endol6 promoter reveals substantial variation within functional sites. Proc Natl Acad Sci 2005, 102(24):859I-8596.

42. Bahar B, Monahan FJ, Moloney AP, Schmidt O, MacHugh D, Sweeney $\mathrm{T}$ : Long-term stability of RNA in post-mortem bovine skeletal muscle, liver and subcutaneous adipose tissues. BMC Mol Biol 2007, 8: 108 .

43. Tamura K, Dudley J, Nei M, Kumar S: MEGA4: molecular evolutionary genetics analysis (MEGA) software version 4.0. Mol Bio Evol 2007, 24(8): 1596-1599.

44. Cargill M, Altshuler D, Ireland J, Sklar P, Ardlie K, Patil N, Lane CR, Lim EP, Kalyanaraman N, Nemesh J, Ziaugra L, Friedland L, Rolfe A, Warrington J, Lipshutz R, Daley GQ, Lander ES: Characterization of single-nucleotide polymorphisms in coding regions of human genes. Nat Genet 1999, 22(3):23I-238.

45. Richardson A, Sisay-Joof F, Ackerman H, Usen S, Katundu P, Taylor T, Molyneux M, Pinder M, Kwiatkowski D: Nucleotide diversity of the TNF gene region in an African village. Genes Immun 200I, 2(6):343-348.

46. Excoffier L, Laval G, Schneider S: Arlequin ver. 3.0: An integrated software package for population genetics data analysis. Evol Bioinform Online 2005, I:47-50.

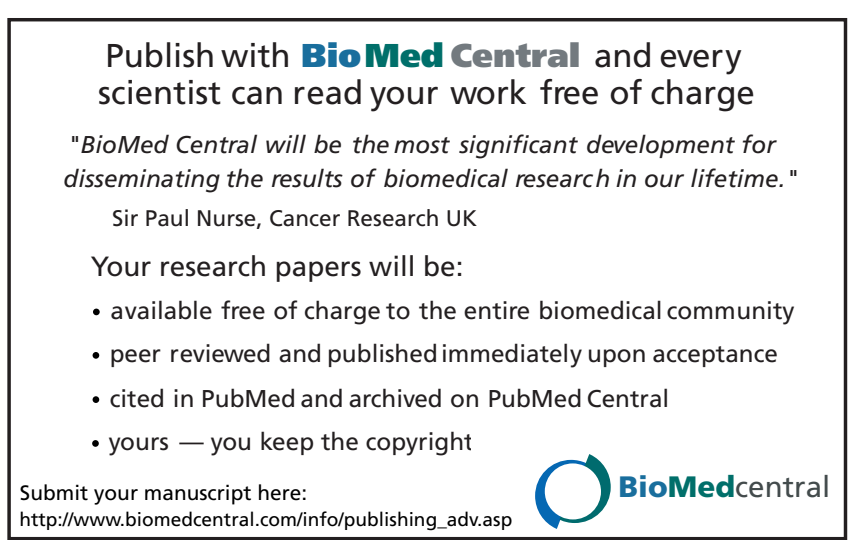

